\title{
Laser capture microdissection and CDNA array analysis of endometrium identify CCLI 6 and CCL2I as epithelial-derived inflammatory mediators associated with endometriosis
}

\author{
Ashwini L Chand*†1, Andrew S Murray ${ }^{\dagger 2,4}$, Rebecca L Jones ${ }^{1,3}$, \\ Natalie J Hannan ${ }^{1}$, Lois A Salamonsen ${ }^{1}$ and Luk Rombauts ${ }^{2}$
}

Address: ${ }^{1}$ Prince Henry's Institute of Medical Research, PO Box 5152, Clayton, Victoria 3168, Australia, ${ }^{2}$ Department of Obstetrics and Gynaecology, Monash University, Clayton, Victoria 3168, Australia, ${ }^{3}$ Division of Human Development, Academic Unit of Child Health, University of Manchester, St Mary's Hospital Research Floor, Hathersage Road, Manchester M13 OJH, UK and ${ }^{4}$ Wellington School of Medicine, Otago University, Wellington, New Zealand

Email: Ashwini L Chand* - ashwini.chand@princehenrys.org; Andrew S Murray - amurray@fertilityassociates.co.nz; Rebecca L Jones - Rebecca.Jones-2@manchester.ac.uk; Natalie J Hannan - natalie.hannan@princehenrys.org; Lois A Salamonsen - lois.salamonsen@princehenrys.org; Luk Rombauts - rombauts@bigpond.net.au

* Corresponding author †Equal contributors

Published: 17 May 2007

Reproductive Biology and Endocrinology 2007, 5:18 doi:10.1/86/1477-7827-5-18

This article is available from: http://www.rbej.com/content/5/I//8

(c) 2007 Chand et al; licensee BioMed Central Ltd.

This is an Open Access article distributed under the terms of the Creative Commons Attribution License (http://creativecommons.org/licenses/by/2.0), which permits unrestricted use, distribution, and reproduction in any medium, provided the original work is properly cited.
Received: I March 2007

Accepted: 17 May 2007

\begin{abstract}
Background: Understanding the pathophysiology of chemokine secretion in endometriosis may offer a novel area of therapeutic intervention. This study aimed to identify chemokines differentially expressed in epithelial glands in eutopic endometrium from normal women and those with endometriosis, and to establish the expression profiles of key chemokines in endometriotic lesions.
\end{abstract}

Methods: Laser capture microdissection isolated epithelial glands from endometrial eutopic tissue from women with and without endometriosis in the mid-secretory phase of their menstrual cycles. Gene profiling of the excised glands used a human chemokine and receptor cDNA array. Selected chemokines were further examined using real-time PCR and immunohistochemistry.

Results: 22 chemokine/receptor genes were upregulated and two downregulated in pooled endometrial epithelium of women with endometriosis compared with controls. CCLI6 and CCL2I mRNA was confirmed as elevated in some women with endometriosis compared to controls on individual samples. Immunoreactive CCLI6 and CCL2I were predominantly confined to glands in eutopic and ectopic endometrium: leukocytes also stained. Immunoreactive CCLI6 was overall higher in glands in ectopic vs. eutopic endometrium from the same woman $(P<0.05)$. Staining for CCLI 6 and CCL2I was highly correlated in individual tissues.

Conclusion: This study provides novel candidate molecules and suggests a potential local role for CCLI6 and CCL2I as mediators contributing to the inflammatory events associated with endometriosis. 


\section{Background}

Endometriosis is defined as the ectopic growth of endometrium-like tissue in locations outside the uterus including the ovaries, the uterine ligaments, the pelvic peritoneum, the Fallopian tubes and the external surface of the uterus. The mechanism/s by which endometriosis develops is still much debated; however retrograde menstruation and subsequent tissue persistence and proliferation is the most accepted theory. The complex question, why some women and not others, develop endometriotic lesions is likely to be due to differences in the local regulation of tissue proliferation, tissue remodelling and inflammatory processes. These observations also raise the question whether the current practice of prompt surgical or medical treatment is always appropriate.

Current evidence suggests that endometriosis-related pain and infertility result from local inflammation at the implant sites, with chemokine-induced recruitment and activation of immune cells [1]. Whilst some chemokines are produced constitutively, the majority (such as CXCL8 (IL-8) and CCL2 (MCP-1)) are induced upon cellular activation by inflammatory stimuli [2-9]. Constitutively expressed chemokines are believed to play a role in basal leukocyte trafficking and secondary lymphoid organ development while induced chemokines help marshal inflammatory, immune and angiogenic responses of the host [10-12]. It is now well established that chemokines also play a role in inflammatory pain sensation (nociception) and cell growth [13]. They are also pivotal in decreased immunologic surveillance, recognition and destruction of ectopic endometrial cells and perhaps facilitation of the implantation of ectopic endometrial tissues $[14,15]$.

It is likely that the cascade of proinflammatory proteins secreted from endometriotic lesions and associated immune cells, dictate the extent of the inflammatory reaction linked with endometriosis, either by facilitating the survival of these lesions or by leading to their demise. Chemokines have been demonstrated to upregulate adhesion molecules and promote invasion of cancer cells [1518]. Such actions could potentially facilitate the attachment and invasion of epithelial cells into the ectopic sites, as observed in cancer metastasis [19]. A number of chemokines have previously been implicated as mediators in the ontogenesis of endometriosis [20]. The levels of monocyte chemotactic protein-1 (MCP-1/CCL2) $[7,8]$; regulated on activation normal T-expressed and secreted (RANTES/CCL5) [21]; interleukin-8 (IL-8/CXCL8) $[22,23]$; and growth-regulated oncogene- $\alpha$ (GRO $\alpha /$ CXCL1) [24] are elevated in the peritoneal fluid of women with endometriosis, and their concentrations correlate with the stage of the disease. Natural Killer (NK) cell activ- ity is also mediated by chemokines and is decreased in patients with endometriosis [25].

Most studies have focused on the peritoneal fluid or serum concentrations of the chemokine of interest rather than its source. The latter may be important as the expression pattern of chemokines in the uterus is remarkably cell-type specific [26]. In addition, the cellular origin of chemokines also varies with cycle stage, although this also differs between individual cytokines $[26,27]$. For example, in the mid-secretory phase of the menstrual cycle, many cytokines are produced predominantly by the epithelial cells, while in the late secretory and menstrual phases, the same cytokines are also strongly expressed in both decidualised stromal cells and leukocytes [26,27], normal peritoneum, peritoneal fluid immune cells, and ectopic endometrial stromal cells [28]. This highlights the importance of examining not just the entire tissue but specific cell types in any tissue where inflammatory cells are abundant or where there are a number of different cell types present. Likewise in disease pathologies including endometriotic lesions, the diseased cells of interest, are surrounded by healthy tissue elements and the cell types of interest may constitute only a small proportion of the volume of the tissue biopsy sample. Laser capture microdissection (LCM) offers a means to overcome inaccuracies arising from analysis of tissues in which there is considerable cellular heterogeneity or in which leukocytes are abundant.

The strengths of two new technologies, LCM and gene array, were utilized in the present study to achieve two main aims. Firstly, to identify chemokines that are differently expressed in glands in eutopic endometrium from normal women and those with endometriosis and secondly, to establish whether these chemokines are also present in glands in endometriotic lesions. Understanding the pathophysiology of chemokine secretion in endometriosis is important as it may offer a novel area of therapeutic intervention. Inhibiting the secretion or action of specific chemokines or blocking their receptors could prevent the inappropriate recruitment of leukocytes to sites of endometriosis-related inflammation. This approach could be considered to act upstream of antiinflammatory therapies available today which, for the most part, act on the cells already at the site of inflammation.

\section{Methods}

\section{Patient details and tissue collection}

Patients undergoing laparoscopy for pelvic pain, investigation of infertility or tubal ligation were recruited at Monash Surgical Private Hospital and at Monash Medical Centre, Moorabbin and Cranbourne Campus, all in greater Melbourne, Australia. Ethical approval was 
obtained from appropriate institutional ethics committees and informed consent was obtained prior to surgery.

Control subjects were those with no laparoscopic evidence of endometriosis. Endometriosis patients were assessed according to the revised American Society of Reproductive Medicine classification system [29]. Eutopic endometrium was obtained from both control and endometriosis patients by standard curettage. Ectopic endometriotic tissue was obtained via laparoscopic excision. Areas biopsied included peritoneum, uterosacral ligaments, and the ovary (endometriomata). Women on any hormonal preparations were excluded from the study. Patient details are provided in Table 1.

Eutopic endometrial tissue sections were designated to menstrual cycle stage by an experienced gynecological pathologist using the established Noyes endometrial dating criteria [30]. For this study, selected tissue samples, derived only from women in the mid-secretory phase (POD 6-10) were assessed for chemokine expression. Endometrial curettings (eutopic tissue) and endometriotic biopsies were snap frozen immediately at $-80^{\circ} \mathrm{C}$ in OCT embedding medium (Sakura Finetek USA Inc., Torrance $\mathrm{CA}, \mathrm{USA}$ ) and stored at $-80^{\circ} \mathrm{C}$ until use.

\section{Tissue preparation for laser capture microdissection}

Sectioning of frozen tissue samples and processing of sections were performed using methods described previously [31]. Frozen tissue blocks were maintained at $-20^{\circ} \mathrm{C}$ and sectioned at $10 \mu \mathrm{m}$, and sections adhered to sterile glass slides (uncharged and uncoated; Objektträger, HD Scientific, Melbourne, Australia) by gentle warming of the slide undersurface and then refreezing at $-20^{\circ} \mathrm{C}$. Sections were then fixed in cold $\left(0^{\circ} \mathrm{C}\right)$ acetone for $1 \mathrm{~min}$, stained with HistoGene (Arcturus Bioscience Inc., CA, USA) for $1 \mathrm{~min}$ and dehydrated in 95\% ethanol (1 wash, $30 \mathrm{sec}$ ), 100\% ethanol (three washes, $30 \mathrm{sec}$ each) and xylene (two washes, $5 \mathrm{~min}$ each). Sections were then allowed to air dry at room temperature and used for laser capture microdissection.

\section{Laser capture microdissection}

Laser capture microdissection (LCM) was used for the isolation of epithelial glands from endometrial eutopic tissue samples. Frozen tissue sections from patients with endometriosis $(\mathrm{n}=4$, marked $*$ in Table 1$)$ and control subjects $(n=4)$ were used for LCM. The PALM ${ }^{\circledR}$ MicroLaser Microdissection System (P.A.L.M. MicroLaser Technologies AG, Burnried, Germany) was utilized. Staining of frozen sections with HistoGene ${ }^{\mathrm{TM}}$ (Arcturus Bioscience Inc., CA, USA) enabled the precise selection of the glandular structures. The laser dissected glands were then ejected off the slide with a single defocused laser pulse and cata-

Table I: Clinical characteristics of endometriosis subjects.

\begin{tabular}{|c|c|c|c|c|c|}
\hline \multicolumn{6}{|c|}{ Endometriosis Patients } \\
\hline Case reference & Age (yr) & AFS stage & Sites of endometriotic lesions & Gravidity & Parity \\
\hline I*\# & 40 & II & Peritoneal & 6 & 4 \\
\hline $2^{* \#}$ & 28 & I & Uterosacral & 0 & 0 \\
\hline $3^{* \#}$ & 28 & II & Peritoneal, Uterosacral & 0 & 0 \\
\hline $4^{*}$ & 29 & II & Peritoneal, Uterosacral & 0 & 0 \\
\hline 5 & 27 & 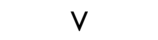 & Uterosacral & 0 & 0 \\
\hline 6 & 37 & V & Ovarian & I & I \\
\hline 7 & 28 & V & Ovarian, Uterosacral, Pouch of Douglas & 1 & 0 \\
\hline 8 & 35 & III & Ovarian & I & I \\
\hline 9 & 37 & IV & Peritoneal & 0 & 0 \\
\hline 10 & 37 & II & Peritoneal & 7 & 4 \\
\hline \multicolumn{6}{|c|}{ Control Subjects } \\
\hline Case reference & Age (yr) & AFS stage & Sites of endometriotic lesions & Gravidity & Parity \\
\hline I*\# & 42 & 0 & - & 0 & 0 \\
\hline $2^{* \#}$ & 46 & 0 & - & 3 & 3 \\
\hline $3 * \#$ & 30 & 0 & - & 4 & 2 \\
\hline $4^{*}$ & 32 & 0 & - & 0 & 0 \\
\hline
\end{tabular}

AFS, American Fertility Society

*used in cDNA array analysis (amplified RNA)

\# used in real-time PCR analysis (unamplified RNA) 
pulted directly into the cap of a microfuge tube containing $10 \mu \mathrm{l}$ droplet of TRIzol (Gibco BRL, Rockville, USA). For each patient, epithelial glands were laser-captured from approximately 20 tissue sections

\section{RNA extraction and purification}

Total RNA was isolated from each LCM sample using the TRIzol method according to manufacturer's instructions (Gibco BRL, Rockville, USA) following an initial incubation with glycogen $(250 \mathrm{ng} / \mu \mathrm{l})$ and TRIzol reagent for 30 min at room temperature to improve yields. RNA samples were stored at $-80^{\circ} \mathrm{C}$.

\section{RNA quantification}

The RNA concentration for each sample was determined with the RiboGreen fluorescence RNA assay (Molecular Probes Europe BV, Leiden, The Netherlands) with an Escherichia coli ribosomal RNA preparation of known concentration as standard and RiboGreen reagent at a final dilution of 1:500. A standard curve of $0-80 \mathrm{ng} /$ well in a 96-well flat-bottomed plate was employed. This assay gave an intra-assay coefficient of variance (CV), as defined by the repeated analysis of a single RNA sample, of 3.3\% $(\mathrm{n}=16)$ and an inter-assay variation of $10.3 \%(\mathrm{n}=14)$. To assess RNA quality and tissue specificity, RNA samples were reverse transcribed and primers specific for a midsecretory phase endometrial gland-specific gene (HtrA3) used for PCR amplification as previously described [32].

\section{RNA amplification}

Amplification of mRNA was performed to achieve the required amount of RNA for cDNA gene arrays. To obtain a representative molecular profile comparison of eutopic endometrium in each of control and endometriosis subject groups, 5 ng of LCM glandular epithelial cell-derived RNA from each of the 4 subjects in the group were pooled. T7 specific RNA amplification of mRNA was performed with the Arcturus HS RNA Amplification Kit (Arcturus) according to manufacturer's instructions. Final RNA yields following amplification, ranged from $0.5 \mu \mathrm{g}$ to $1.5 \mu \mathrm{g}$.

\section{Gene array}

Gene profiling was conducted using the GeArray Q Series Human Chemokine and Receptor Gene Array (SuperArray Bioscience Corp., Bethesda, USA) consisting of 77 chemokine and chemokine receptor CDNA probes, printed in quadruplicate on a nylon membrane. Glyceraldehyde-3phosphate dehydrogenase (GAPDH), cyclophilin and $\beta$ actin were included as positive controls and PUC18 plasmid DNA as a negative control. The gene array experiments were performed as previously described [27].

For each array experiment, 100 ng amplified RNA was reverse transcribed to CDNA using Moloney murine leukemia virus-reverse transcriptase (MLTV-RTase) (Promega,
Annandale, NSW, Australia) in the presence of biotinylated uridine 5-triphosphate (udTP) (Roche), and incubated overnight in hybridization buffer (SuperArray) containing $100 \mu \mathrm{g} / \mathrm{ml}$ denatured sheared salmon sperm DNA (Invitrogen Australia, Pty. Ltd., Mount Waverley, Vic, Australia) with pre-hybridized nylon arrays at $68^{\circ} \mathrm{C}$. Post-hybridization washes with saline/sodium citrate/ sodium dodecyl sulfate (SSC/SDS) were also conducted at $68^{\circ} \mathrm{C}$. Positive cDNA binding was detected by application of a streptavidin-alkaline phosphatase conjugate in blocking solution and chemiluminescent substrate, CDP-Star as supplied with the arrays (SuperArray).

Membranes were exposed to X-ray film for a range of times between $2 \mathrm{sec}$ and $5 \mathrm{~min}$, to ensure quantitation during the linear phase of the reaction. Arrays for the two subject groups were conducted simultaneously, and the entire experiment was then repeated. X-ray films were scanned at high resolution and densitometrically analyzed using GelDoc software (Bio-Rad Laboratories, Regents Park, NSW, Australia). Chemokine signals were normalized for background signal intensity, to correct for exposure times. Gene expression for each array was also normalised to cyclophilin expression levels. Fold changes in gene expression of 2-fold or higher were considered as significantly different.

\section{Real time RT-PCR}

To confirm array data and to determine the variability between subjects, real time RT-PCR was performed on unamplified RNA derived from individual LCM samples from endometriosis and control groups $(n=3$ per group: insufficient starting material was available for the remaining 2 samples). Total unamplified RNA (5 $\mathrm{ng}$ ) was reverse transcribed using avian myeloblastosis virus-reverse transcriptase (AMV-RTase) (Promega, NSW, Australia) and 1 ng random hexanucleotide primers (Amersham Biosciences, NJ, USA), and the cDNA generated was subsequently amplified by PCR for specific primer pairs encoding CCL16, CCL21 and 18S RNA genes (for primer sequence refer to [27]).

The Roche Light Cycler Real-time PCR system was used (Roche Diagnostics Australia Pty Ltd, NSW, Australia) where $4 \mu \mathrm{l}$ cDNA (diluted 1 in 10) was added to a master mix including SYBR Green I, deoxynucleotide triphosphates, Taq polymerase enzyme, optimized concentrations of $\mathrm{MgCl}_{2}$, and specific primers ( $0.5 \mathrm{pmol} / \mu \mathrm{l}$; Sigma Genosys, Australia Pty. Ltd., NSW, Australia). An initial denaturing step was performed for $10 \mathrm{~min}$ at $95^{\circ} \mathrm{C}$, before 40 cycles of $95^{\circ} \mathrm{C}$ for $15 \mathrm{sec}, 55-66^{\circ} \mathrm{C}$ for $5 \mathrm{sec}$ (annealing temperature specific to primer pair [27]) and $72^{\circ} \mathrm{C}$ for 10 sec. All samples to be compared were included within the same run and the entire PCR experiment was performed in duplicate. 
Expression of mRNA was quantitated by comparison with a 6-point standard curve of serially diluted (10-fold) cDNA standards specific to the gene product. The standard doses ranged between $2.5 \mathrm{ng} / \mu \mathrm{l}$ and $0.5 \mathrm{fg} / \mu \mathrm{l}$. Fluorescence from incorporation of SYBR green into doublestranded PCR products was monitored continuously during cycling at the end of each elongation phase, and quantitation of mRNA expression was performed when amplified products were in the log-linear phase and parallel to the standards. A quality control (a single endometrial cDNA sample) was included in every run. At the end of each program, melting curve analysis was carried out to ensure specificity of the reaction products. The sizes of the products were confirmed by gel electrophoresis and DNA sequenced to confirm identity for selected samples. Data was normalized for the expression of $18 \mathrm{~S}$ RNA.

\section{Immunohistochemistry}

For the further verification of gene array and real time RTPCR data, frozen sections from 3 of the 4 same endometriosis patients and control subjects, along with tissue sections from an additional 8 normal and 7 endometriosis subjects, were used for the immunohistochemical comparison of chemokine (CCL16 and CCL21) protein expression ( $\mathrm{n}=12$ and 10 respectively per group). Glands were not found in the frozen endometriotic lesion of one endometriosis patient who had been included in the array study and this subject was thus excluded from this part of the study. Affinity-purified polyclonal antibodies raised against human CCL21 and CCL16 peptides (Santa Cruz Biotechnology, Santa Cruz, CA, USA) were utilized for immunohistochemistry as previously described [27]. Positive controls (normal eutopic endometrium) previously shown to have positive staining for CCL16 and CCL21, were included in every run. Negative controls were sections of each tissue included on the same slide but with non-immune IgG at the same concentration substituted for the primary antibodies. For immunostaining, $10 \mu \mathrm{m}$ sections were post-fixed in 10\% buffered formalin for 10 min, rehydrated and exposed to microwave antigen retrieval for $5 \mathrm{~min}$ before cooling. Primary antibodies were applied overnight $(17 \pm 1 \mathrm{~h})$ at $4{ }^{\circ} \mathrm{C}$, diluted to $4 \mu \mathrm{g} /$ $\mathrm{ml}$ in non-immune block containing $10 \%$ horse serum (Sigma-Aldrich, Sydney, Australia) and 2\% human serum (in-house) in TBS with $0.1 \%$ Tween 20.

Detection of positive binding was performed by the sequential application of biotinylated horse anti-goat IgG (1:200 in nonimmune block; Vector Laboratories, Burlingame, CA, USA) and avidin-biotin-peroxidase conjugate (Dako, Glostrup, Denmark), followed by the substrate diaminobenzidine (Dako) for between 2 and $10 \mathrm{~min}$. Sections were counterstained with Harris' hematoxylin (Sigma), dehydrated and mounted from Histosol with DPX mounting medium (BDH Laboratory Supplies,
Poole, UK). Immunostaining was assessed semi-quantitatively by two independent assessors, blind to the identity of subject groups. Blinding was not possible in the assessment of ectopic tissue potentially biasing the results. Staining intensity and heterogeneity for each endometrial compartment (epithelium, stroma, leukocytes and vasculature) was assessed and allocated a score between 0 and 4 where 0 = no stain, 1 = faint staining, 2 = moderate staining, 3 = strong staining and $4=$ maximally intense staining.

\section{Statistical analysis}

None of the data were normally distributed and therefore non-parametric tests were used. The direct comparison of two samples from different patients was conducted with the Mann-Whitney U-test. The direct comparison of two samples (eutopic and ectopic endometrium) from the same patient was conducted with the Wilcoxon MatchedPairs Signed-Ranks Test. For the relationship between two independent interval variables (staining intensities for CCL16 and CCL21) the rank correlation coefficient was used. The significance level was set at a $P$ value of $<0.05$.

\section{Results}

Laser capture microdissection

Laser capture technology enabled the isolation of glandular epithelial cells from mid-secretory phase endometrial tissue of control and endometriosis subjects ( $n=4$ per group) (Figure 1A and 1B). For each subject, $150-600$ glands were microdissected from 10 to 20 individual frozen tissue sections of $10 \mu \mathrm{m}$ in thickness. Extraction of RNA of the LCM cells produced RNA yields of varying quantities ranging from $0.18 \mathrm{ng}$ to $1.15 \mathrm{ng}$ per glandular structure isolated (Figure 1C). The positive amplification of the epithelial-specific gene product, Htra3, ascertained that glandular epithelial cells had been specifically isolated and RNA integrity retained (Figure 1C).

\section{Gene array}

To provide a global chemokine expression profile in eutopic endometrium from normal women and endometriosis patients, and to overcome patient to patient variability, total RNA extracted from LCM glandular epithelial cells was pooled from 4 individuals in each group (Table 1). Of 77 genes profiled on the cDNA gene arrays, expression of 22 chemokine and receptors were reproducibly (two separate runs) upregulated in pooled endometrium from women with endometriosis compared with controls (Table 2). Downregulation of expression was observed in 11 genes; however only 2 of these demonstrated a 2 -fold or higher difference when compared to expression levels in normal endometrium (Table 3). For many upregulated genes, fold increase was not quantifiable, due to the lack of detectable expression in the control pool compared to very high expression in the endometriosis pool. In con- 


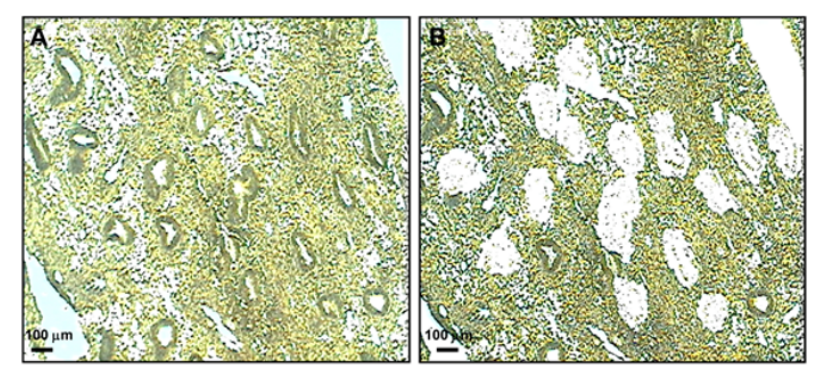

C

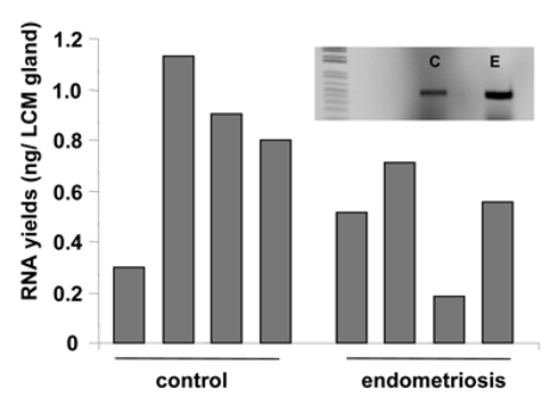

Figure I

Laser capture microdissection. (A) Frozen section of eutopic endometrial tissue from an endometriosis patient (mid-secretory phase) stained with HistoGene ${ }^{\mathrm{TM}}$. The epithelial glands were isolated with laser capture microdissection (LCM). (B) Tissue section following LCM demonstrating the precision in dissection and cell capture. (C) RNA yields from microdissected glands expressed as total RNA (ng) per number of gland from each tissue sample. Microdissected glandular RNA samples from control $(C, n=4)$ and endometriosis $(E, n=4)$ tissues were separately, reverse transcribed and a uterine epithelial cell-specific gene (HtrA3) was amplified using PCR to assess RNA quality (insert).

trast, the fold-change quantified in genes which were downregulated was relatively small, with the largest difference being a 2.5-fold decrease in CCL28 expression.

\section{Real-time RT PCR}

To verify the results obtained from cDNA array experiments and to establish the variability between individuals, two candidate genes (CCL16 and CCL21, also known as HCC-4 and 6C-kine respectively) that had not previously been identified as associated with endometriosis, were selected for further analysis using quantitative realtime RT-PCR on individual unamplified RNA samples of glands from eutopic tissue (patients and controls: $\mathrm{n}=3$ subjects per cohort). All 3 samples used for each cohort, in this analysis, were included in cDNA array analysis. Selection of the candidate genes was based on the marked upregulation of mRNA levels on the cDNA arrays. These chemokines have been previously characterised in normal cycling human endometrium in our laboratory [27], the mRNA for CCL16 and CCL21 is maximal in entire endometrium during the mid-secretory phase of the menstrual cycle. In this study, mRNA expression for CCL16 was below the detection limit in the LCM glands from all 3 controls and 1 of the 3 endometriosis patient samples (Figure 2A). Where detectable, expression levels ranged from $0.01-0.05 \mathrm{fg} / \mathrm{pg} 18 \mathrm{~S}$ RNA. Overall there was a significant elevation in eutopic endometrial glandular CCL16 expression in women with endometriosis compared to controls $(\mathrm{n}=3 ; \mathrm{P}=0.049)$.

CCL21 mRNA was more abundant than that of CCL16 and was markedly elevated in eutopic glands from one endometriosis patient (mean, $0.61 \mathrm{fg} / \mathrm{pg} 18 \mathrm{~S}$ RNA) (Figure $2 \mathrm{~B}$ ). The levels of CCL21 observed in the remaining endometriosis patients ranged from $0.02-0.19 \mathrm{fg} / \mathrm{pg} 18 \mathrm{~S}$ RNA. In the control cohort, CCL21 mRNA expression ranged between $0.003-0.045 \mathrm{fg} / \mathrm{pg} 18 \mathrm{~S}$ RNA. These combined data clearly show that the expression of CCL16 and CCL21 is disturbed at least in some patients with endometriosis. In women without endometriosis the expression was consistently low.

\section{Chemokine immunohistochemistry in control and endometriosis eutopic tissue}

Since the findings from the cDNA array and real time RTPCR experiments supported a role for CCL21 and CCL16 in at least some women with endometriosis, immunohistochemistry was performed to establish the presence and cellular location of the protein for these 2 chemokines in eutopic and ectopic endometrial samples. Immunoreactivity for both chemokines was evident in glandular epithelial cells but absent from stromal cells and was overall in accord with the real-time PCR quantitation. CCL16 protein was detected in the glandular epithelium of all but one of the 32 tissues examined and CCL21 protein was evident in glands in all tissues. However, staining was variable between individual tissues even within groups (Figure 3). No significant differences were detected for either CCL1 6 or CCL21 between mean glandular staining intensity in endometrium from normal women compared with eutopic endometrium from women with endometriosis (Figure 3). The staining pattern in some glands was predominantly apical (Figures 4A-C) suggesting secretion of the chemokine into the uterine lumen. Within each tissue, all glands were equally stained and staining was present in all cells in each gland (Figures 4A-D).

\section{Chemokine immunohistochemistry in matched eutopic and ectopic endometriosis tissue}

Comparisons were also made between the immunostaining in matched eutopic and ectopic endometrium in endometriosis patients. Positive staining was present in ectopic tissue for both CCL16 and CCL21 (Figures 3 and 4). In both cases, chemokines specifically localised in epithelial cells of glandular structures in ectopic lesions 
Table 2: Upregulated genes in glandular epithelial cells of eutopic endometrium: endometriosis compared with controls.

\begin{tabular}{|c|c|c|c|c|c|}
\hline $\begin{array}{l}\text { Regulated gene } \\
\text { for chemokines }\end{array}$ & Common name & Fold change & $\begin{array}{l}\text { Associa-ted with } \\
\text { receptors }\end{array}$ & $\begin{array}{l}\text { Functional expression on immune } \\
\text { cells }\end{array}$ & Gene accession \\
\hline CCLI5 & $\mathrm{HCC} 2$ & ++ & CCRI, CCR3 & T-lymphocytes, monocytes & NM_004167 \\
\hline CCLI6 & $\mathrm{HCC} 4$ & ++ & CCRI & Monocytes & NM 004590 \\
\hline CCLI8 & PARC & ++ & unknown & T-lymphocytes & NM 002988 \\
\hline CCLI9 & MIP-3 $\beta$ & ++ & CCR7 & T-cell and B-lymphocytes. & NM 006274 \\
\hline CCL2I & 6Ckine & ++ & CCR7 & Leukocytes, endothelial cells & NM_002989 \\
\hline CCL22 & MDC & $2.2(1.6,2.9)$ & CCR4 & Leukocytes, natural killer cells & NM 002990 \\
\hline CCL23 & MPIF-I & ++ & CCRI & $\begin{array}{l}\text { T-cell lymphocytes, Monocytes, } \\
\text { Neutrophils }\end{array}$ & NM 001295 \\
\hline CXCL5 & ENA-78 & $2.1(1.5,2.6)$ & CXCR2 & $\begin{array}{l}\text { Works in conjunction with IL8 to activate } \\
\text { neutrophils }\end{array}$ & NM 002994 \\
\hline CXCL8 & IL8 & $2.2(1.5,2.5)$ & CXCR2 & $\begin{array}{l}\text { T-cell lymphocyte and neutrophil } \\
\text { chemoattractant }\end{array}$ & NM 000584 \\
\hline CXCLIO & I-PIO & ++ & CXCR3 & $\begin{array}{c}\text { Monocytes, natural killer cells, T-cell } \\
\text { lymphocytes }\end{array}$ & NM 001565 \\
\hline CXCLI3 & BCA-I & $3.0(1.9,3.7)$ & CXCR5 & B- and T-cell lymphocytes & NM 006419 \\
\hline XCLI & lymphotactin & ++ & XCRI & B- and T-cell lymphocytes & NM 005283 \\
\hline XCL2 & SCM-I $\beta$ & ++ & XCRI & T-cell lymphocytes & NM 003175 \\
\hline $\mathrm{CX}_{3} \mathrm{CLI}$ & Fractalkine & $16.4(2.2,30.6)$ & $\mathrm{CX}_{3} \mathrm{CRI}$ & $\mathrm{T}$ cells, monocytes & NM 002996 \\
\hline
\end{tabular}

\begin{tabular}{|c|c|c|c|c|c|}
\hline Receptors & & & Ligand & & \\
\hline CCRI/CD234 & $\begin{array}{l}\text { Duffy antigen receptor for } \\
\text { chemokines (DARC) }\end{array}$ & $2.2(1.5,2.6)$ & CXCLI, CXCL5, CXCL8 & Erythrocytes, leukocytes, Endothelial cells & NM 002036 \\
\hline CCRIO & GPR2 & ++ & CCL27 & T-cells & NM 016602 \\
\hline CXCR2 & IL-8R $\beta$ & ++ & CXCL8 & Neutrophils & NM 001557 \\
\hline CXCR4 & fusin & ++ & CXCLI2 & $\begin{array}{l}\text { T-and B-cell lymphocytes, monocytes, } \\
\text { macrophages }\end{array}$ & NM 003467 \\
\hline CXCR5 & BLRI & $2.5(2,2.8)$ & CXCLI3 & B- and T-cell lymphocytes & NM 001716 \\
\hline CXCR6 & TYMSTR & $5.8(4.1,7.5)$ & CXCLI6 & T-cell lymphocytes & NM 006564 \\
\hline XCRI & GPR55 & ++ & XCLI XCL2 & $\mathrm{T}$ cells, mast cells, monocytes, macrophages & NM 005283 \\
\hline LTB4R* & GPRI6 & $1.9(1.4,42.2)$ & leukotriene B4 (LTB4) & Neutrophils & NM 181657 \\
\hline
\end{tabular}

++ Fold upregulation > 20 fold; in most cases cDNA hybridization signal was undetectable in control arrays but clearly detectable in endometriosis arrays. Where difference in expression was quantifiable and variable between the 2 arrays, fold change is presented in parentheses.

*not a chemokine receptor, is a potent chemoattractant and survival factor for neutrophilic polymorphonuclear (PMN) leukocytes (59, 60)

derived from ovarian, uterosacral ligaments and peritoneal sites. In some ectopic peritoneal lesions, large irregular cyst-like structures were present and strong staining for both CCL16 and CCL21 was apparent in glandular epithelial cells and in secretions within the cyst. In other peritoneal lesions, but more commonly, in ovarian lesions, glandular formation was very structured, closely resembling eutopic tissue morphology. Very strong staining was seen in glands in some ectopic lesions (one lesion for CCL16 (Figure 4E) and three for CCL21). Overall glandular staining intensity was higher in ectopic tissue than in eutopic tissue and this reached significance $(P=0.047)$ for CCL16. Importantly, there was a high degree of correlation between staining for CCL16 and CCL21 in each sample (Rank correlation coefficient $\mathrm{R}=0.81, P<0.001$ ).

Leukocytes were evident in most tissues and stained strongly for CCL16 and CCL21: these were highly abundant in some lesions (Figure 4F insert) emphasizing the importance of laser capture microdissection in this study. Inclusion of leukocytes in the original cDNA array analysis would have skewed the data. As negative controls, endometrial sections with non-immune IgG substituted for the primary antibodies, demonstrated no localised staining (Figures 4G-H).

\section{Discussion}

This study used laser capture dissection and pathway-specific gene array analysis to determine chemokines that may be expressed at elevated levels during the mid-secretory phase in the glandular epithelium of the endometrium of women with endometriosis when compared to controls. Using pooled samples, 22 genes were markedly upregulated while only 2 genes were slightly downregulated in the endometriosis cohort. Real-time PCR verified that there were differences in the mRNA encoding CCL16 and CCL21, the two chemokines selected for further study, but that there was considerable heterogeneity in expression in individual endometriosis subjects. This heterogeneity was confirmed at the protein level. Furthermore, immunoreactive CCL16 was more intensely stained in epithelium in ectopic endometriosis lesions compared with matched eutopic tissue, and there was a similar trend for CCL21. Indeed, there was high correlation between staining for these two chemokines in each sample. This data thus adds CCL16 and CCL21 to the chemokines found to be elevated in endometriosis sup- 
porting a role for chemokines in the pathogenesis of endometriosis. Given the small patient cohort assessed, definitive conclusions cannot be drawn: however the current study provides preliminary data on the involvement of previously unidentified chemokines in the pathogenesis of endometriosis.

Despite the technical difficulties in obtaining sufficient quantities of mRNA with LCM, the current study clearly highlights the importance of laser capture microdissection for the accurate analysis of cell-specific gene expression in heterogeneous tissues such as endometrium. In this tissue, epithelial cells are the predominant source of chemokines [27], many of which are maximally expressed in the mid secretory phase. However, both decidualized stromal cells (found only in late secretory endometrium) and leukocytes are variably abundant in endometrium throughout the menstrual cycle and are additional sources of chemokines. By isolation and initial analysis of glandular epithelium from endometrium, we have been able to identify epithelial-derived chemokines and have excluded the variability and likely spurious results that would have been caused by the presence of infiltrating leukocytes, which also produce chemokines [27].

Laser capture microdissection and RNA amplification technology have been used previously for gene expression profiling of the glandular epithelium in endometriosis patients and aberrant expression was noted in genes relating to oxidative stress and focal adhesion and in genes linked to Wnt, PI3K and RAS/RAF/MAPK signalling [3335]. As there are no reports of chemokine expression profiling in endometriosis, the present study is the first to provide a comprehensive list of potential candidate chemokines and receptors in laser-captured glandular epithelium in eutopic endometrium from women with endometriosis.

Selected chemokines identified as being of potential interest from the array analysis were further examined by semiquantitative real-time PCR analysis. Importantly, individual samples were assessed at this stage, to establish not only the variability between the two study groups, but also that between individuals. In laser captured glands from control subjects, CCL16 and CCL21 mRNA were uniformly undetectable or at low levels. In contrast, in women with endometriosis, eutopic CCL16 and CCL21 mRNA levels were increased in some subjects but with significant patient-to-patient variability. This variability could be attributed both to the heterogeneity of the disease, both in cause and phenotype and also to differences in endometrial morphology from individual to individual. Subsequent immunohistochemical examination of the protein however, showed somewhat different results. More tissues were used for this analysis and staining intensities of the two chemokines in the glands were very variable between individuals. Interestingly the major differences in protein were seen between eutopic and ectopic tissues in the same women, with overall higher staining intensity in ectopic tissue. The discrepancy between mRNA and protein levels may reflect either rapid clearance of mRNA or the stability of immunoreactive protein.

The precise roles of CCL16 and CCL21 in the endometrium are currently unknown, but there is considerable information regarding their functions in immunological disease and cancer. CCL16 is specifically chemotactic for monocytes [36-38]. It increases antigen presentation of macrophages, enhances T-cell cytotoxicity and stimulates their production of a number of inflammatory-type cytokines (IL-1 $\beta, \mathrm{TNF} \alpha, \mathrm{IL}-12$ ) [37]. A recent study showed that CCL16 stimulated cell migration of human osteogenic sarcoma cells expressing CCR1 [39]. It is also found to be overexpressed in synovial tissue from patients with inflammatory joint disease [40]. CCL16 has low sequence homology (30\%) to other CCR1-dependent chemokines, and significant structural differences, particularly in the $\mathrm{N}$-terminal region required for receptor activation [41]. This may explain why CCL16, although binding to a non-specific receptor, triggers a unique signalling cascade and provides evidence of differential regulatory mechanisms employed by chemokines to illicit cellular responses.

CCL21 has known functions in homeostasis, in the reconstitution of lymphocytes and in immuno-surveillance [42]. It activates T-cells and lymphocytes [43], attracts both T- and B-cells and dendritic cells (DC) to lymphoid tissues through its receptor CCR7. It is essential for the priming of naive T-cells in the initiation phase of the immune response $[44,45]$. CCL21 has also been implicated in the abnormal adhesion and migration of CD $34^{+}$ cells in leukemia [46]. How an elevation of CCL21 may contribute to endometriosis is not certain. However, elevations in expression of this normally constitutive chemokine have been reported in cases of chronic inflammation/pathology and autoimmune diseases where a role in inappropriate recruitment of naïve T-cells to non-lymphoid tissue has been proposed $[47,48]$. Interestingly, endometriosis has been likened to an autoimmune disease [49].

In addition to their upregulation in eutopic endometrium from women with endometriosis, examination of CCL16 and CCL21 in ectopic tissues demonstrated a significant increase in protein relative to expression in eutopic tissue derived from the same individual. A similar observation has been documented recently with the induction of endometriosis in a baboon model with no prior disease [50]. Following the inoculation of endometriosis tissue 
Table 3: Downregulated genes in glandular epithelial cells of eutopic endometrium: endometriosis compared with controls.

\begin{tabular}{|c|c|c|c|c|c|}
\hline $\begin{array}{l}\text { Regulated gene for } \\
\text { chemokines }\end{array}$ & Common name & Fold change & Associated receptor & Functional expression on immune cells & Gene accession \\
\hline CCL28 & MEC & $2.5(1.1-1.7)$ & CCRIO & T-cell lymphocytes, Eosinophils, & NM_019846 \\
\hline CCL4 & MIPI $\beta / A C T-2$ & $2.0(1.3-3.3)$ & CCR6 & $\begin{array}{c}\text { B- and T-cell lymphocytes, neutrophils, macrophages, } \\
\text { monocytes }\end{array}$ & NM 002984 \\
\hline
\end{tabular}

into the peritoneal cavity of the animal, a concomitant increase in cysteine-rich angiogenic inducer 61 (CYR61) gene expression was measured both in eutopic and ectopic tissues. This observation suggests it is the presence of the endometriotic lesions, which directly influences the local environment in the endometrium. In our immunolocalization study of the ectopic lesions, typical large cyst-like structures containing much cellular debris/secretion strongly stained for the chemokines, suggesting secretion of chemokines apically from the epithelial cells. However, the level of chemokine expression did not correlate with the severity of the endometriosis.

CXCL8 (IL-8), another chemokine whose mRNA was increased in endometrial glands from women with endometriosis in our array study, has previously been studied in depth with regard to a role in endometriosis [51], further substantiating our gene array results. CXCL-8 levels are elevated in peritoneal fluid in women with endometriosis [51-53]. Furthermore, glandular epithelial cell localisation and upregulation of immunoreactive CXCR1 and CXCR2, which bind CXCL8, has been demonstrated in eutopic and ectopic tissue sections from endometriosis patients when compared to controls [54].

The data from this pathway-specific gene array thus provides new evidence for the broad dysregulation of chemokine expression in both eutopic endometrial epithelium and ectopic lesions of women with endometriosis. The glandular chemokines which were upregulated are known to recruit and activate natural killer cells, $\mathrm{T}$ and $\mathrm{B}$ lymphocytes, monocytes and neutrophils. Collectively, such upregulation of chemokines and receptors, in endometriosis patients may demonstrate an increased ability of the endometrium and endometriotic lesions to recruit leukocytes and thus exacerbate the inflammatory response.

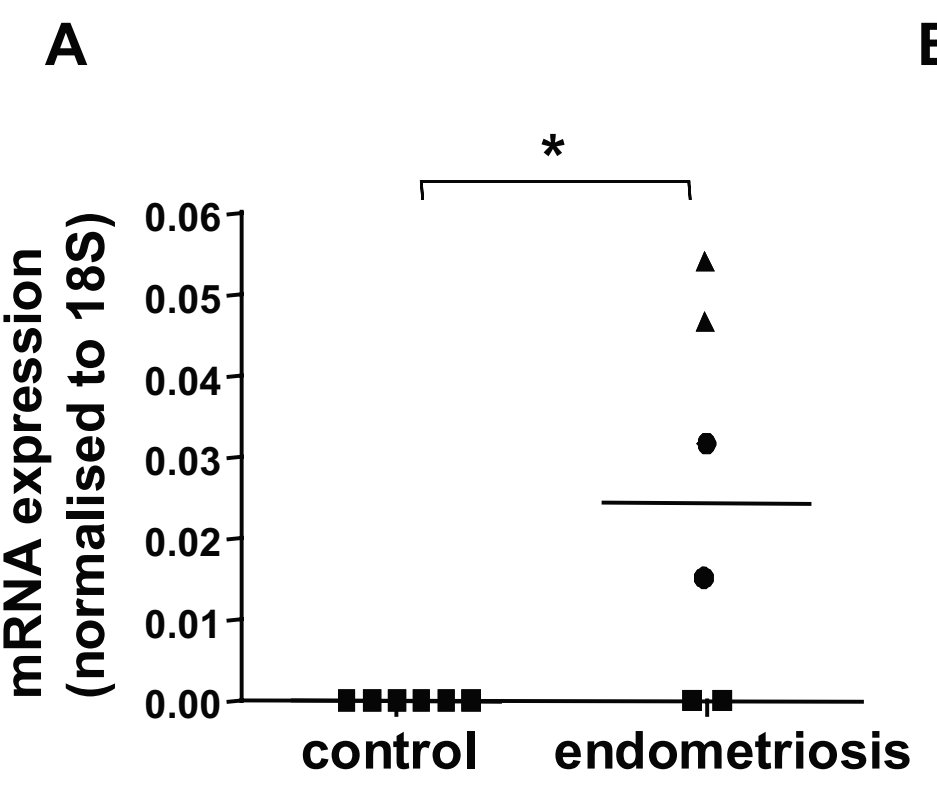

B

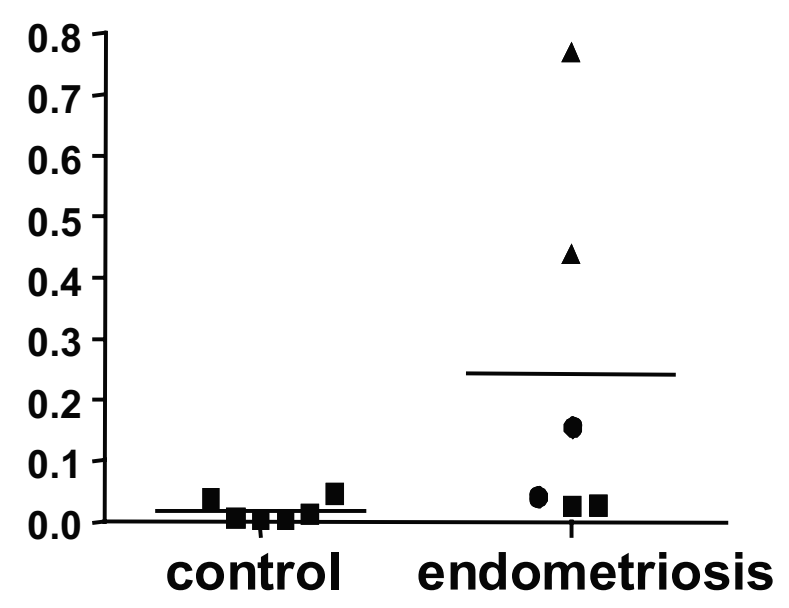

Figure 2

Real-time PCR quantitation of CCLI 6 and CCL2I mRNA expression in control and endometriosis subjects. (A) mRNA expression of CCLI6 and (B) CCL2I was measured in glandular RNA samples from individuals in control ( $\mathbf{\square})$ and endometriosis cohorts $(\boldsymbol{Q}, \boldsymbol{O}, \boldsymbol{\Delta}$ representing the 3 patients' individual data). Data is presented as relative units where chemokine expression has been normalized to I8S RNA expression for each sample ( $n=3$ per group, RT-PCR performed in duplicates). The average value for each subject group is indicated with a horizontal line. * denotes a statistically significant difference between the 2 groups ( $P=0.049$, Mann-Whitney $U$-test $)$. 


\section{CCL16}

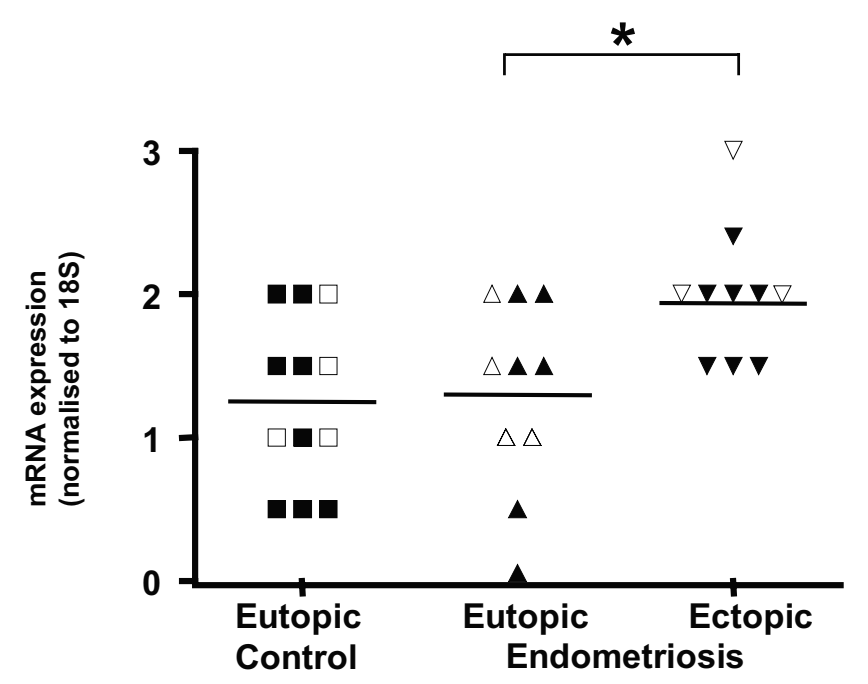

CCL21

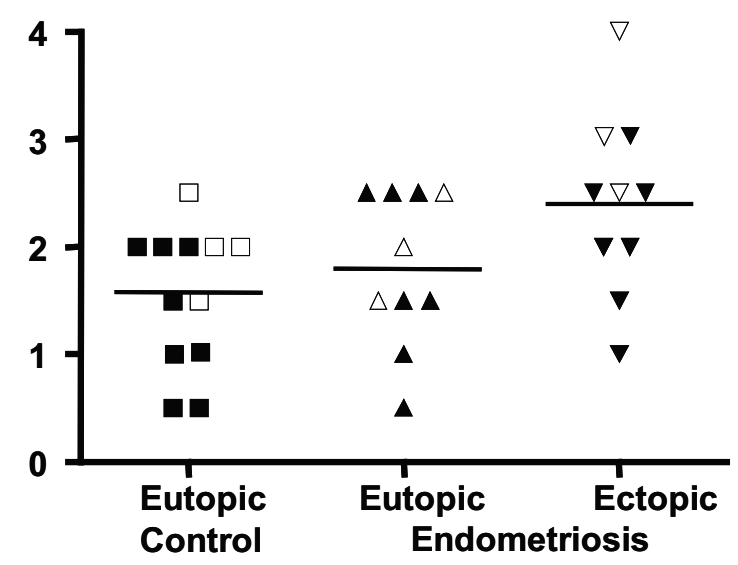

\section{Figure 3}

Immunostaining for CCLI 6 and CCL2I in eutopic and ectopic tissue from control and endometriosis subjects. Staining intensity for (A) CCLI 6 and (B) CCL2I in glandular epithelium of normal mid secretory endometrium ( $n=12)(\square)$ and in glandular epithelium in paired eutopic $(\boldsymbol{\Delta})$ and ectopic $(\boldsymbol{\nabla})$ endometrium from women with endometriosis $(n=10)$, also in the mid-secretory phase of the menstrual cycle. Open symbols represent subjects whose samples were used in the gene array study. Staining intensity was scored on a scale of 0 (no stain) to 4 (intense stain). Scores are shown for individual samples. Bars represent mean values. $*$ denotes a statistical difference between 2 samples from the same patients $(P=0.047$, Wilcoxon Matched-Pairs Signed-Ranks Test).

Aberrant chemokine expression in the uterine lumen may interfere with blastocyst implantation and hence provide one rationale for the infertility that is often associated with endometriosis. The invasive trophoblast and the eutopic endometrium strongly express chemokine receptors (CCR1, CCR10, CCR5, CCR7, CXCR4, CXCR6 and $\mathrm{XCR}$ ) and chemokines contribute to the positioning, adhesion and migration of trophoblast [55-58]. Chemokines also have non-immune functions during tissue remodelling and in many diseases through upregulation of adhesion molecule expression, angiogenesis, cell proliferation and motility [59]. The higher abundance of chemokines in endometriosis may facilitate tissue adherence of retrograde menstrual tissue, increase epithelial cell proliferation and remodelling to form glandular structures, and stimulate tissue breakdown and bleeding. There is some functional evidence in support of a role of chemokines in increasing tissue adherence. In a recent study, treatment of mice with a broad-spectrum chemokine inhibitor (NR58-3.14.3) reduced the size and number of post-operative intra-peritoneal adhesions [60] and in particular, a reduction in CD45+ inflammatory cell accumulation within the adhesions was observed.

\section{Conclusion}

In conclusion, the current study has identified potential new candidate molecules from the chemokine family that may be important in the pathogenesis of endometriosis. The use of laser capture microdissection was fundamental to identify only those chemokines and chemokine receptors derived from the epithelial compartment. Further, two novel candidate molecules, CCL16 and CCL21, not previously linked to endometriosis have been validated. This data supports the hypothesis that the inflammatory phenotype observed in endometriosis may involve the activation of chemokine cascades.

\section{Competing interests}

The author(s) declare that they have no competing interests.

\section{Authors' contributions}

ALC carried out tissue collection, laser capture microdissection molecular studies, analysed all data and drafted the manuscript. ASM participated in the design and coordination of the study, recruited patients, performed surgery including tissue excision, performed laser capture 

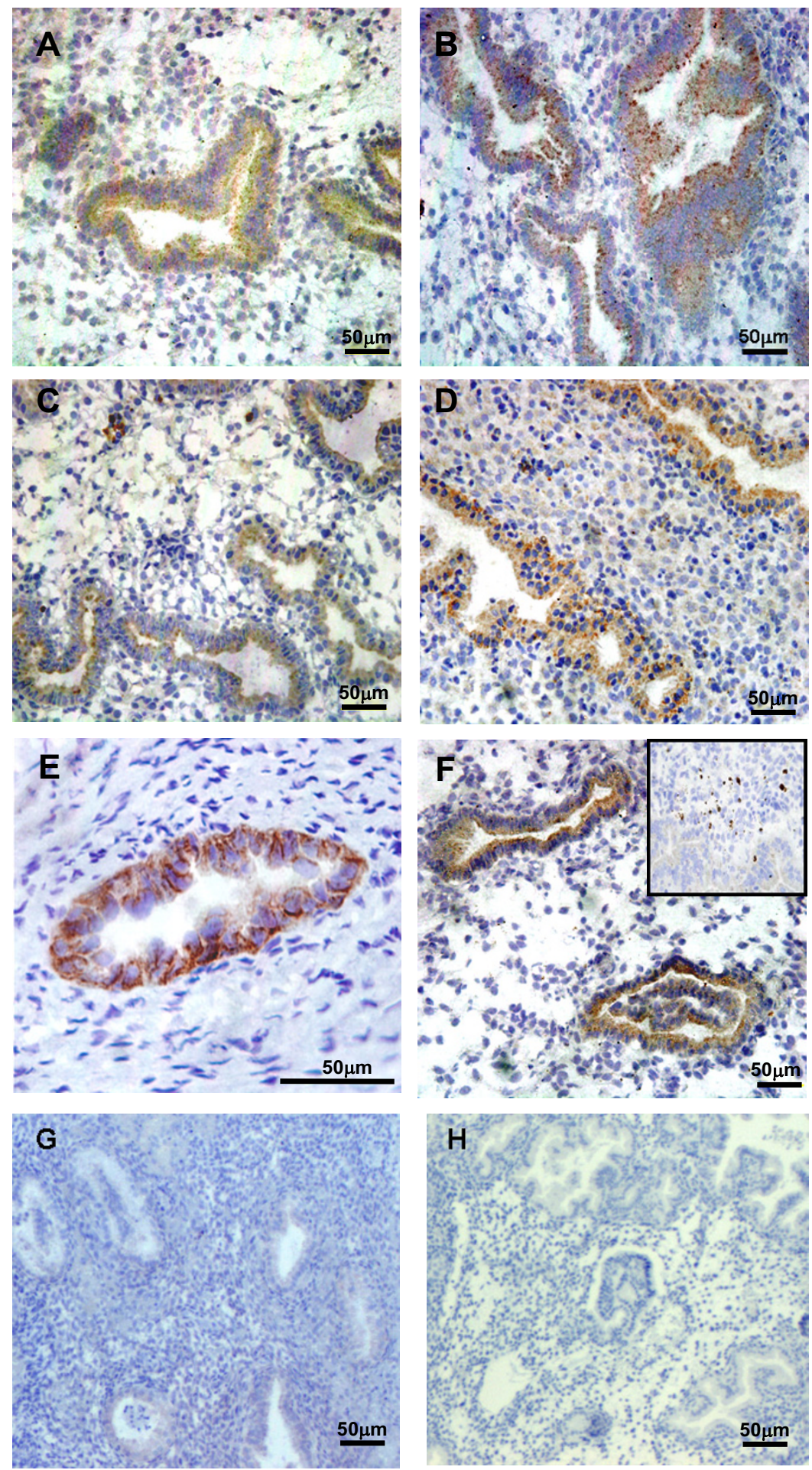

\section{Figure 4}

Immunostaining for CCLI 6 and CCL2 I. Representative tissues immunostained for CCLI6 (A, C, E) and CCL2I (B, D, F). CCLI 6 and CCL2I staining, in control eutopic endometrial tissue (A, B), eutopic tissue (C, D), and matched ectopic lesions (E, F) from the same endometriosis patient. Leukocytes stained for CCL2I are shown in the insert in (F). (G, H) Endometrial sections with non-immune $\lg G$ substituted for the primary antibodies, as negative controls. Scale bars represent $200 \mu \mathrm{m}$. 
microdissection and helped to draft the manuscript. RLJ participated in the design of the study and helped to draft the manuscript. NJH and JZ performed the immunohistochemistry. LAS participated in the conception of the study, its design and coordination and helped to draft the manuscript. LR participated in the conception of the study, its design and coordination, performed the statistical analysis and helped to draft the manuscript.

\section{All authors read and approved the final manuscript.}

\section{Acknowledgements}

This study was funded by grants from the Mayne Nickless Women's Health Fellowship by the Royal Australian and New Zealand College of Obstetricians and Gynecologists (ASM) and the Monash Medical Faculty Grant (LR). LAS, RLJ and NJH were supported by the NHMRC of Australia (38890 I and 241000).

We are grateful to the patients who generously consented for their tissues for this study. We are also grateful to $\operatorname{Dr} B$ Vollenhoven, Dr A. Lawrence, and $\mathrm{Dr}$ M. Lawrence, for their assistance in the collection of biopsy material.

\section{References}

I. Lebovic DI, Mueller MD, Taylor RN: Immunobiology of endometriosis. Fertil Steril 200I, 75: I- 10.

2. Tseng JF, Ryan IP, Milam TD, Murai JT, Schriock ED, Landers DV, Taylor RN: Interleukin-6 secretion in vitro is up-regulated in ectopic and eutopic endometrial stromal cells from women with endometriosis. J Clin Endocrinol Metab 1996, 81: I I I 8-I I 22.

3. Rier SE, Parsons AK, Becker JL: Altered interleukin-6 production by peritoneal leukocytes from patients with endometriosis. Fertil Steril 1994, 6 I:294-299.

4. Zeyneloglu HB, Senturk LM, Seli E, Bahtiyar OM, Olive DL, Arici A The peritoneal fluid levels of interleukin- 12 in women with endometriosis. Am J Reprod Immunol 1998, 39:152-156.

5. Moser B, Loetscher P: Lymphocyte traffic control by chemokines. Nat Immunol 200I, 2:I23-I28.

6. Ryan IP, Tseng JF, Schriock ED, Khorram O, Landers DV, Taylor RN: Interleukin-8 concentrations are elevated in peritoneal fluid of women with endometriosis. Fertil Steril 1995, 63:929-932.

7. Akoum A, Lemay A, Brunet C, Hebert J: Secretion of monocyte chemotactic protein-I by cytokine-stimulated endometrial cells of women with endometriosis. Le groupe d'investigation en gynecologie. Fertil Steril 1995, 63:322-328.

8. Akoum A, Lemay A, McColl S, Turcot-Lemay L, Maheux R: Elevated concentration and biologic activity of monocyte chemotactic protein- $I$ in the peritoneal fluid of patients with endometriosis. Fertil Steril 1996, 66:17-23.

9. Zeyneloglu HB, Senturk LM, Seli E, Oral E, Olive DL, Arici A: The role of monocyte chemotactic protein- $I$ in intraperitoneal adhesion formation. Hum Reprod 1998, 13:1 194-1199.

10. Luther SA, Cyster JG: Chemokines as regulators of $\mathbf{T}$ cell differentiation. Nat Immunol 200I, 2: I02-107.

II. Mantovani A, Allavena P, Vecchi A, Sozzani S: Chemokines and chemokine receptors during activation and deactivation of monocytes and dendritic cells and in amplification of ThI versus Th2 responses. Int J Clin Lab Res 1998, 28:77-82.

12. Mantovani A, Allavena P, Sozzani S, Vecchi A, Locati M, Sica A: Chemokines in the recruitment and shaping of the leukocyte infiltrate of tumors. Semin Cancer Biol 2004, I 4: I 55-160.

13. Boddeke EW: Involvement of chemokines in pain. Eur J Pharmacol 2001, 429: II5-II9.

14. Barcz E, Kaminski P, Marianowski L: Role of cytokines in pathogenesis of endometriosis. Med Sci Monit 2000, 6: 1042-1046.

15. Garcia-Velasco JA, Arici A: Interleukin-8 stimulates the adhesion of endometrial stromal cells to fibronectin. Fertil Steril 1999, 72:336-340.
16. Fernandis AZ, Prasad A, Band H, Klosel R, Ganju RK: Regulation of CXCR4-mediated chemotaxis and chemoinvasion of breast cancer cells. Oncogene 2004, 23:157-167.

17. Scotton CJ, Wilson JL, Scott K, Stamp G, Wilbanks GD, Fricker S, Bridger G, Balkwill FR: Multiple actions of the chemokine CXCLI 2 on epithelial tumor cells in human ovarian cancer. Cancer Res 2002, 62:5930-5938.

18. Mareel M, Leroy A: Clinical, cellular, and molecular aspects of cancer invasion. Physiol Rev 2003, 83:337-376.

19. Lee BC, Lee TH, Avraham S, Avraham HK: Involvement of the chemokine receptor CXCR4 and its ligand stromal cellderived factor I alpha in breast cancer cell migration through human brain microvascular endothelial cells. Mol Cancer Res 2004, 2:327-338.

20. Lin YJ, Lai MD, Lei HY, Wing LY: Neutrophils and macrophages promote angiogenesis in the early stage of endometriosis in a mouse model. Endocrinology 2006, I47: I278-1286.

21. Khorram O, Taylor RN, Ryan IP, Schall TJ, Landers DV: Peritoneal fluid concentrations of the cytokine RANTES correlate with the severity of endometriosis. Am J Obstet Gynecol 1993, 169:1545-1549.

22. Arici A, Tazuke SI, Attar E, Kliman HJ, Olive DL: Interleukin-8 concentration in peritoneal fluid of patients with endometriosis and modulation of interleukin-8 expression in human mesothelial cells. Mol Hum Reprod 1996, 2:40-45.

23. Gazvani MR, Christmas S, Quenby S, Kirwan J, Johnson PM, Kingsland CR: Peritoneal fluid concentrations of interleukin-8 in women with endometriosis: relationship to stage of disease. Hum Reprod 1998, 13:1957-1961.

24. Szamatowicz J, Laudanski P, Tomaszewska I, Szamatowicz M: Chemokine growth-regulated-alpha: a possible role in the pathogenesis of endometriosis. Gynecol Endocrinol 2002, 16:|37-|4|.

25. Ho HN, Wu MY, Yang YS: Peritoneal cellular immunity and endometriosis. Am J Reprod Immunol 1997, 38:400-4I2.

26. Hannan NJ, Jones RL, Critchley HO, Kovacs GJ, Rogers PA, Affandi B, Salamonsen LA: Coexpression of fractalkine and its receptor in normal human endometrium and in endometrium from users of progestin-only contraception supports a role for fractalkine in leukocyte recruitment and endometrial remodeling. J Clin Endocrinol Metab 2004, 89:6 I I 9-6I 29.

27. Jones RL, Hannan NJ, Kaitu'u TJ, Zhang J, Salamonsen LA: Identification of chemokines important for leukocyte recruitment to the human endometrium at the times of embryo implantation and menstruation. J Clin Endocrinol Metab 2004, 89:6155-6167.

28. Kyama CM, Overbergh L, Debrock S, Valckx D, Vander Perre S, Meuleman C, Mihalyi A, Mwenda JM, Mathieu C, D'Hooghe TM: Increased peritoneal and endometrial gene expression of biologically relevant cytokines and growth factors during the menstrual phase in women with endometriosis. Fertil Steril 2006, 85: 1667-1675.

29. Medicine ASR: Revised American Society for Reproductive Medicine classification of endometriosis: 1996. Fertil Steril 1997, 67:817-821.

30. Noyes RW Hertig A.T., Rock, J.: Dating of Endometrial Biopsy. Am J Obstet Gynecol 1975, 1 22:262-263.

31. Sluka P, O'Donnell L, Stanton PG: Stage-specific expression of genes associated with rat spermatogenesis: characterization by laser-capture microdissection and real-time polymerase chain reaction. Biol Reprod 2002, 67:820-828.

32. Nie GY, Li Y, Minoura H, Batten L, Ooi GT, Findlay JK, Salamonsen LA: A novel serine protease of the mammalian HtrA family is up-regulated in mouse uterus coinciding with placentation. Mol Hum Reprod 2003, 9:279-290.

33. Matsuzaki S, Canis M, Vaurs-Barriere C, Pouly JL, Boespflug-Tanguy O, Penault-Llorca F, Dechelotte P, Dastugue B, Okamura K, Mage G: DNA microarray analysis of gene expression profiles in deep endometriosis using laser capture microdissection. Mol Hum Reprod 2004, 10:719-728.

34. Matsuzaki S, Canis M, Vaurs-Barriere C, Boespflug-Tanguy O, Dastugue B, Mage G: DNA microarray analysis of gene expression in eutopic endometrium from patients with deep endometriosis using laser capture microdissection. Fertil Steril 2005, 84 Suppl 2:1180-1190.

35. Wu Y, Kajdacsy-Balla A, Strawn E, Basir Z, Halverson G, Jailwala P, Wang Y, Wang X, Ghosh S, Guo SW: Transcriptional character- 
izations of differences between eutopic and ectopic endometrium. Endocrinology 2006, 147:232-246.

36. Hedrick JA, Helms A, Vicari A, Zlotnik A: Characterization of a novel CC chemokine, HCC-4, whose expression is increased by interleukin-10. Blood 1998, 91:4242-4247.

37. Cappello P, Caorsi C, Bosticardo M, De Angelis S, Novelli F, Forni G, Giovarelli M: CCLI6/LEC powerfully triggers effector and antigen-presenting functions of macrophages and enhances T cell cytotoxicity. J Leukoc Biol 2004, 75: I35- I 42.

38. Nakayama T, Kato Y, Hieshima K, Nagakubo D, Kunori Y, Fujisawa T, Yoshie O: Liver-expressed chemokine/CC chemokine ligand 16 attracts eosinophils by interacting with histamine $\mathrm{H} 4$ receptor. J Immunol 2004, 1 73:2078-2083.

39. Kim IS, Jang SW, Sung HJ, Lee JS, Ko J: Differential CCRI-mediated chemotaxis signaling induced by human CC chemokine HCC-4/CCLI 6 in HOS cells. FEBS Lett 2005, 579:6044-6048.

40. Haringman JJ, Smeets TJ, Reinders-Blankert P, Tak PP: Chemokine and chemokine receptor expression in paired peripheral blood mononuclear cells and synovial tissue of patients with rheumatoid arthritis, osteoarthritis, and reactive arthritis. Ann Rheum Dis 2006, 65:294-300.

41. Youn BS, Zhang S, Broxmeyer HE, Antol K, Fraser MJ Jr., Hangoc G, Kwon BS: Isolation and characterization of LMC, a novel lymphocyte and monocyte chemoattractant human CC chemokine, with myelosuppressive activity. Biochem Biophys Res Commun 1998, 247:217-222.

42. Nagira M, Imai T, Hieshima K, Kusuda J, Ridanpaa M, Takagi S, Nishimura M, Kakizaki M, Nomiyama H, Yoshie O: Molecular cloning of a novel human CC chemokine secondary lymphoid-tissue chemokine that is a potent chemoattractant for lymphocytes and mapped to chromosome 9p/3. J Biol Chem 1997, 272:19518-19524.

43. Christopherson KW 2nd, Campbell JJ, Hromas RA: Transgenic overexpression of the CC chemokine CCL2I disrupts T-cell migration. Blood 200I, 98:3562-3568.

44. Flanagan K, Moroziewicz D, Kwak H, Horig H, Kaufman HL: The lymphoid chemokine CCL2I costimulates naive $T$ cell expansion and ThI polarization of non-regulatory CD4+ $T$ cells. Cell Immunol 2004, 23 I:75-84.

45. Kikuchi K, Yanagawa Y, Onoe K: CCR7 ligand-enhanced phagocytosis of various antigens in mature dendritic cells-time course and antigen distribution different from phagocytosis in immature dendritic cells. Microbiol Immunol 2005, 49:535-544.

46. Jongen-Lavrencic M, Salesse S, Delwel R, Verfaillie CM: BCR/ABLmediated downregulation of genes implicated in cell adhesion and motility leads to impaired migration toward CCR7 ligands CCL19 and CCL2I in primary BCR/ABL-positive cells. Leukemia 2005, 19:373-380.

47. Grant AJ, Goddard S, Ahmed-Choudhury J, Reynolds G, Jackson DG, Briskin M, Wu L, Hubscher SG, Adams DH: Hepatic expression of secondary lymphoid chemokine (CCL2I) promotes the development of portal-associated lymphoid tissue in chronic inflammatory liver disease. Am / Pathol 2002, 160: | 445- | 455.

48. Bonacchi A, Petrai I, Defranco RM, Lazzeri E, Annunziato F, Efsen E, Cosmi L, Romagnani P, Milani S, Failli P, Batignani G, Liotta F, Laffi G, Pinzani M, Gentilini P, Marra F: The chemokine CCL2I modulates lymphocyte recruitment and fibrosis in chronic hepatitis C. Gastroenterology 2003, I 25:1060-1076.

49. Matarese G, De Placido G, Nikas Y, Alviggi C: Pathogenesis of endometriosis: natural immunity dysfunction or autoimmune disease? Trends Mol Med 2003, 9:223-228.

50. Gashaw I, Hastings JM, Jackson KS, Winterhager E, T. FA: Induced Endometriosis in the Baboon (Papio anubis) Increases the Expression of the Proangiogenic Factor CYR6I (CCNI) in Eutopic and Ectopic Endometria. Biol Reprod 2006.

51. Arici A: Local cytokines in endometrial tissue: the role of interleukin-8 in the pathogenesis of endometriosis. Ann $N$ Y Acad Sci 2002, 955: 101-9; discussion II 8, 396-406.

52. Iwabe T, Harada T, Tsudo T, Tanikawa M, Onohara Y, Terakawa N: Pathogenetic significance of increased levels of interleukin-8 in the peritoneal fluid of patients with endometriosis. Fertil Steril 1998, 69:924-930.

53. Arici A, Seli E, Senturk LM, Gutierrez LS, Oral E, Taylor HS: Interleukin-8 in the human endometrium. J Clin Endocrinol Metab 1998, 83: 1783-1787.
54. Ulukus M, Ulukus EC, Seval Y, Zheng W, Arici A: Expression of interleukin-8 receptors in endometriosis. Hum Reprod 2005, 20:794-80I.

55. Dominguez F, Galan A, Martin J], Remohi J, Pellicer A, Simon C: Hormonal and embryonic regulation of chemokine receptors CXCRI, CXCR4, CCR5 and CCR2B in the human endometrium and the human blastocyst. Mol Hum Reprod 2003, 9: $189-198$.

56. Hannan NJ, Jones RL, White CA, Salamonsen LA: The Chemokines, CX3CLI, CCLI4, and CCL4, Promote Human Trophoblast Migration at the Feto-Maternal Interface. Biol Reprod 2006.

57. Drake PM, Red-Horse K, Fisher SJ: Reciprocal chemokine receptor and ligand expression in the human placenta: implications for cytotrophoblast differentiation. Dev Dyn 2004, 229:877-885

58. Sato $Y$, Higuchi T, Yoshioka S, Tatsumi K, Fujiwara H, Fujii S: Trophoblasts acquire a chemokine receptor, CCRI, as they differentiate towards invasive phenotype. Development 2003, 130:5519-5532.

59. Banas B, Wornle M, Berger T, Nelson PJ, Cohen CD, Kretzler M, Pfirstinger J, Mack M, Lipp M, Grone HJ, Schlondorff D: Roles of SLC/CCL2I and CCR7 in human kidney for mesangial proliferation, migration, apoptosis, and tissue homeostasis. J Immunol 2002, I 68:430I-4307.

60. Berkkanoglu M, Zhang L, Ulukus M, Cakmak H, Kayisli UA, Kursun S, Arici $A$ : Inhibition of chemokines prevents intraperitoneal adhesions in mice. Hum Reprod 2005, 20:3047-3052.

6I. Gaudreault E, Stankova J, Rola-Pleszczynski M: Involvement of leukotriene B4 receptor I signaling in platelet-activating factormediated neutrophil degranulation and chemotaxis. Prostaglandins Other Lipid Mediat 2005, 75:25-34.

62. Stankova J, Turcotte S, Harris J, Rola-Pleszczynski M: Modulation of leukotriene B4 receptor-I expression by dexamethasone: potential mechanism for enhanced neutrophil survival. J Immunol 2002, 168:3570-3576.

Publish with Biomed Central and every scientist can read your work free of charge

"BioMed Central will be the most significant development for disseminating the results of biomedical research in our lifetime. "

Sir Paul Nurse, Cancer Research UK

Your research papers will be:

- available free of charge to the entire biomedical community

- peer reviewed and published immediately upon acceptance

- cited in PubMed and archived on PubMed Central

- yours - you keep the copyright 